\title{
Trade Openness and Women Participation in the Labor Market: Evidence from South Asia
}

\author{
Liton Chandra Voumik* \\ Lecturer, Department of Economics, Noakhali Science and Technology University, Bangladesh
}

\begin{abstract}
This paper seeks to investigate the impact of trade openness on women labor force participation in South Asian countries. The paper also controls GDP per capita, women literacy rate, urban population, unemployment rate, male labor force participation and other attributes. I will check the robustness of a variety of different approaches in dealing with the various models to trade openness. The paper also examines both push and pull factors induced or not women to join the labor force. Thus, a country that is exporting female labor stuff is actually recruiting more female labor and expand employment of female labors. The focus of this paper lies on the effects of trade openness on women's participation in the labor market.
\end{abstract}

Keywords: female labor force participation, trade openness, South Asia, international trade

DOI: $10.7176 / \mathrm{JCSD} / 50-02$

Publication date:July $31^{\text {st }} 2019$

\section{Introduction}

Women participating in economic activities in an ongoing fact across advanced, developing (particularly South Asian) and underdeveloped countries. UNDP, 2013 and World Economic Forum, 2014 declared that women are increasingly distinguished as the wheeler of sustainable economic development. South Asian countries play an excellent context to study the impact of trade openness on female labor market outcomes.

South Asian Countries' labor force survey, 2010 showed that economically active women population is 910.67 millions, and female labor force is 430.72 millions. On the other hand, women out of labor force are 470.95 millions. (Source: BBS). Once some South Asian countries (India, Bangladesh, Nepal, and Sri Lanka) was protected counties in the world, their government embarked on some policies, yet gradual, tariff reductions after the 1980s, opening export processing zones (EPZs) in 1990s, focusing export-oriented economy in 1990s as a response to GATT, WTO, and WB negotiations. It has been widely acknowledging that these reforms had profound effects on widening labor markets, poverty reduction, increasing wages, economic growth, exports, and other outcomes (Rahman, M.M. 2011; Mohammad Monjurul Hoque et al, 2012) So, trade policy reform has expanded South Asian economy's size as well as labor force participation. I will not only estimate the effects of trade liberalization on female labor market participation, but examine a wider range of female labor market outcomes (including employment in different sectors such as services, industries, and agricultures). The focus of this study is to understand channels through which two major economic factors, international trade, and female labor force participation, are connected.

\section{Trade Openness and Women Welfare}

Through the free exchange of goods, capital, and services, countries can specialize according to their comparative advantage. Countries can concentrate on producing goods for export that they manufacture at comparatively lower costs and less resources and on importing goods that can be produced in another country more cheaply. Lower average cost can specialize industries and exploit economies of scale because exporting opens up a bigger market and enables the production of more goods. As a result, industries distribute resources more efficiently, achieve economic of scale, and attain higher productivity, which boosts the value of national output, GDP, exports, and thus real income.

There are two channels in which trade openness could improve the welfare of women. These are higher income for the countries on the macro level, and higher income for women on the micro level. First, trade openness could increase a countries' revenues, growth, and per capita income and thus let governments provide more public goods, security, and welfare services. In a macro perspective, if higher levels of trade generate more income for the country, then trade changes the capacity of governments to meet the needs of the population: for example, for social protection, schools, and health facilities. On the other hand, in the micro level trade openness could improve individuals by improving their wage, average income, overtime opportunity, and employment opportunity. Trade openness could improve the industrialization, investment, and production in various ways. That improve the welfare of women. Particularly, as women's wage, employment opportunities, education, job security goes up, the opportunity cost of skipping labor market for the sake of house works, child bearing, and leisure increasing (Engelhardt \& Prskawetz, 2004; Rees and Apps, 2001). 
3. Literature Reviews

\begin{tabular}{|c|c|c|c|}
\hline Authors/ Year/ Title & Short Description & Data Description & Key Regression \\
\hline $\begin{array}{l}\text { Janna Besamusca, Kea } \\
\text { Tijdens, Maarten Keune } \\
(2015) \text {. Working } \\
\text { Women Worldwide. } \\
\text { Age Effects in Female } \\
\text { Labor Force } \\
\text { Participation in } 117 \\
\text { Countries }\end{array}$ & $\begin{array}{l}\text { They find different outcomes } \\
\text { for different age groups. } \\
\text { When paid maternity leave } \\
\text { exists women are more likely } \\
\text { to participate in the labor } \\
\text { market. }\end{array}$ & $\begin{array}{l}\text { The authors collected a } \\
\text { unique country-level } \\
\text { dataset of female labor } \\
\text { force participation, } \\
\text { several age groups and } \\
\text { selected indicators that } \\
\text { can be attributed to the } \\
117 \text { countries. }\end{array}$ & $\begin{array}{l}\text { Dependent Variable is } \\
\text { FLFP, Independent } \\
\text { Variables are age, } \\
\text { education, GDP, } \\
\text { services, religions, } \\
\text { maternity, health, and } \\
\text { others. }\end{array}$ \\
\hline $\begin{array}{l}\text { Isis G. and Janneke P. } \\
(2012) \text {. Trade } \\
\text { Liberalization and } \\
\text { Female Labor Force } \\
\text { Participation: Evidence } \\
\text { from Brazil }\end{array}$ & $\begin{array}{l}\text { Investigates the impact of } \\
\text { Brazil's trade liberalization on } \\
\text { labor force participation of } \\
\text { women. Findings suggest that } \\
\text { both push and pull factors } \\
\text { encouraged women to join the } \\
\text { labor force. }\end{array}$ & $\begin{array}{l}\text { Data collected from } \\
\text { Brazil National } \\
\text { Household Sample } \\
\text { Survey (PNAD), and } \\
\text { Brazilian Census } \\
\text { Bureau. }\end{array}$ & $\begin{array}{l}\text { Dependent Variable is } \\
\text { female labor market } \\
\text { outcomes and } \\
\text { Independent Variables } \\
\text { are trade protections and } \\
\text { time varying control } \\
\text { variables }\end{array}$ \\
\hline $\begin{array}{l}\text { Asma Hyder, Jere R. } \\
\text { Behrman (2012). } \\
\text { International trade } \\
\text { openness and gender } \\
\text { gaps in Pakistani labor } \\
\text { force participation rates } \\
\text { over } 57 \text { years }\end{array}$ & $\begin{array}{l}\text { The findings indicate that } \\
\text { increased international trade } \\
\text { significantly decreases the gap } \\
\text { between male and female } \\
\text { labor force participation on } \\
\text { average across all occupations. }\end{array}$ & $\begin{array}{l}\text { The authors use five } \\
\text { rounds of Pakistan's } \\
\text { Census data and two } \\
\text { recent nationwide } \\
\text { Labor Force Surveys } \\
\text { (2002-2003 and 2006- } \\
2007)\end{array}$ & $\begin{array}{l}\text { Dependent Variable is } \\
\text { Difference between male } \\
\text { and female LFPR in } \\
\text { occupational category; } \\
\text { Independent variables } \\
\text { are trade openness, } \\
\text { different categories of } \\
\text { profession. }\end{array}$ \\
\hline $\begin{array}{l}\text { Ramessur, Taruna } \\
\text { Shalini Sobhee, and } \\
\text { Sanjeev K (2009), } \\
\text { Impact of trade } \\
\text { liberalization on labor } \\
\text { conditions on the textile } \\
\text { sector of Mauritius: the } \\
\text { fate of female workers }\end{array}$ & $\begin{array}{l}\text { Their findings reveal that trade } \\
\text { liberalization would make it } \\
\text { more problematic for female } \\
\text { workers to negotiate wage } \\
\text { increases in the long run as } \\
\text { these may entail significant } \\
\text { employment cuts in the Export } \\
\text { Processing Zone (EPZ). }\end{array}$ & $\begin{array}{l}\text { The data sources } \\
\text { contain industrial } \\
\text { Statistics and also } \\
\text { numerous reports } \\
\text { published by the } \\
\text { Mauritius Export } \\
\text { Processing Zone } \\
\text { Association (MEPZA). }\end{array}$ & $\begin{array}{l}\text { Dependent Variable is } \\
\text { measured as total } \\
\text { employment in each } \\
\text { firm, Independent } \\
\text { Variables are male- } \\
\text { female ratio, wage, and } \\
\text { liberalization dummy }\end{array}$ \\
\hline $\begin{array}{l}\text { Richards, David; Ronald } \\
\text { Gelleny, (2007). } \\
\text { Women's status and } \\
\text { economic globalization, } \\
\text { International Studies } \\
\text { Quarterly, Vol 41, Issue } \\
4 .\end{array}$ & $\begin{array}{l}\text { They find the relationship } \\
\text { between economic } \\
\text { globalization and women's } \\
\text { status varies by type and era. } \\
\text { Also economic globalization } \\
\text { is associated with improved } \\
\text { women's status }\end{array}$ & $\begin{array}{l}\text { The authors used a } \\
\text { pooled cross-sectional } \\
\text { time-series dataset } \\
\text { composed of } 130 \\
\text { countries for the years } \\
1982 \text { to } 2003\end{array}$ & $\begin{array}{l}\text { Dependent Variable is } \\
\text { women status, } \\
\text { Independent Variables } \\
\text { are trade openness, FDI, } \\
\text { portfolio investment, and } \\
\text { economic development. }\end{array}$ \\
\hline $\begin{array}{l}\text { Cem Baslevent (2004), } \\
\text { The Effect of Export- } \\
\text { Oriented Growth on } \\
\text { Female Labor Market } \\
\text { Outcomes in Turkey. } \\
\text { World development, Vol } \\
32 \text {. }\end{array}$ & $\begin{array}{l}\text { This paper analyzes the impact } \\
\text { of export-oriented growth } \\
\text { strategy on female labor force } \\
\text { participation and employment } \\
\text { in urban Turkey. }\end{array}$ & $\begin{array}{l}\text { The data from the two } \\
\text { rounds of the } \\
\text { Household Labor Force } \\
\text { Surveys conducted by } \\
\text { the State Institute of } \\
\text { Statistics of Turkey } \\
\text { (SIS). }\end{array}$ & $\begin{array}{l}\text { The author applied } \\
\text { Probit model. Dependent } \\
\text { Variable is female labor } \\
\text { force participation, } \\
\text { Independent Variables } \\
\text { are- age, married, GDP, } \\
\text { and GDP growth. }\end{array}$ \\
\hline $\begin{array}{l}\text { Bussmann, Margit } \\
(2009) \text {, The Effect of } \\
\text { Trade Openness on } \\
\text { Women 's Welfare and } \\
\text { Work Life. World } \\
\text { Development, 37(6), } \\
\text { 1027-1038. }\end{array}$ & $\begin{array}{l}\text { He finds positive effects of } \\
\text { trade (exports to GDP, import } \\
\text { penetration) on female } \\
\text { labor force participation in } \\
\text { non-OECD countries, but } \\
\text { negative effects in OECD } \\
\text { countries, on the } \\
\text { basis of GMM estimations for } \\
1970 \text { to } 2000 \text {. }\end{array}$ & $\begin{array}{l}\text { The data is cross- } \\
\text { section, based on } 134 \\
\text { countries }\end{array}$ & $\begin{array}{l}\text { Dependent Variable is } \\
\text { here women wellbeing, } \\
\text { Independent Variables } \\
\text { are globalization index, } \\
\text { women schooling, } \\
\text { women health and others }\end{array}$ \\
\hline
\end{tabular}




\begin{tabular}{|l|l|l|l|}
\hline Authors/ Year/ Title & Short Description & Data Description & Key Regression \\
\hline $\begin{array}{l}\text { Revenga Ana(1997), } \\
\text { Employment and Wage }\end{array}$ & $\begin{array}{l}\text { She found that trade } \\
\text { liberalization affected on firm- } \\
\text { Effects of Trade } \\
\text { Liberalization: The Case } \\
\text { of Mexican } \\
\text { Manufacturing }\end{array}$ & $\begin{array}{l}\text { The data used here are } \\
\text { plant level data from } \\
\text { Annual Industrial } \\
\text { Survey }\end{array}$ & $\begin{array}{l}\text { The dependent variable } \\
\text { is real annual earning, } \\
\text { independent variables } \\
\text { are average wage, tariff, } \\
\text { price of raw materials, }\end{array}$ \\
\hline
\end{tabular}

\section{Theory and Literature}

The theory relies on an assumption concerning labor supply that is consistent with comparative advantage between male and female labor supply. Trade openness pushes manufacturing industries to export in South Asian Countries because of lower production cost. The lower production cost seeks lower labor cost. In most of the south Asian countries, women labors' wage is cheaper than male.

Previously south Asian women are largely excluded from access to paid industries, manufacturing, or services work. Trade openness provided more women with the paid wage for formal and informal sectors. Another channel is the trade openness promotes economic growth, aids poverty alleviation and enhancing gender equality and reducing wage gap that increases the women participation in the job market.

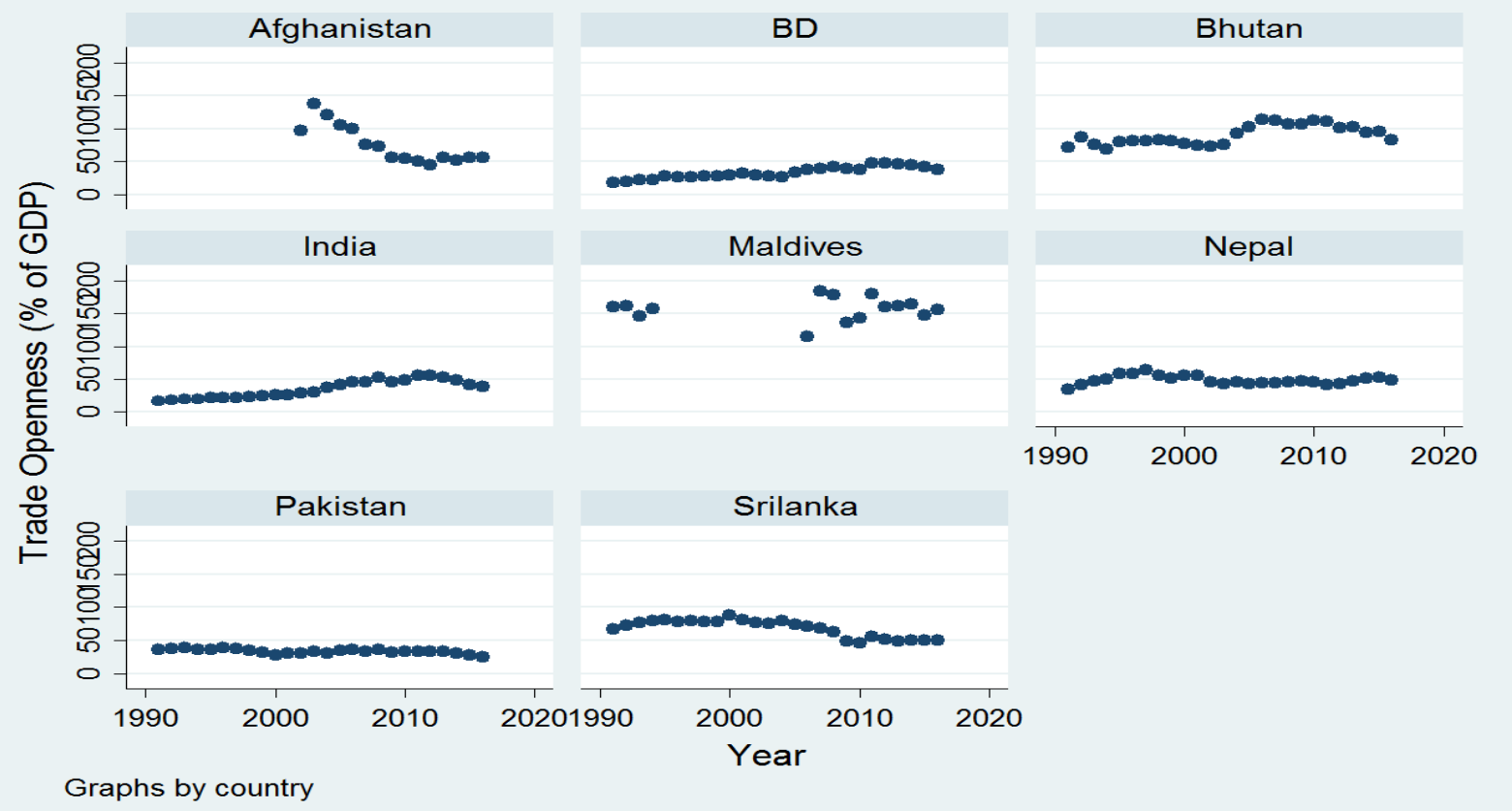

Figure 1. Trade openness by time for South Asian countries

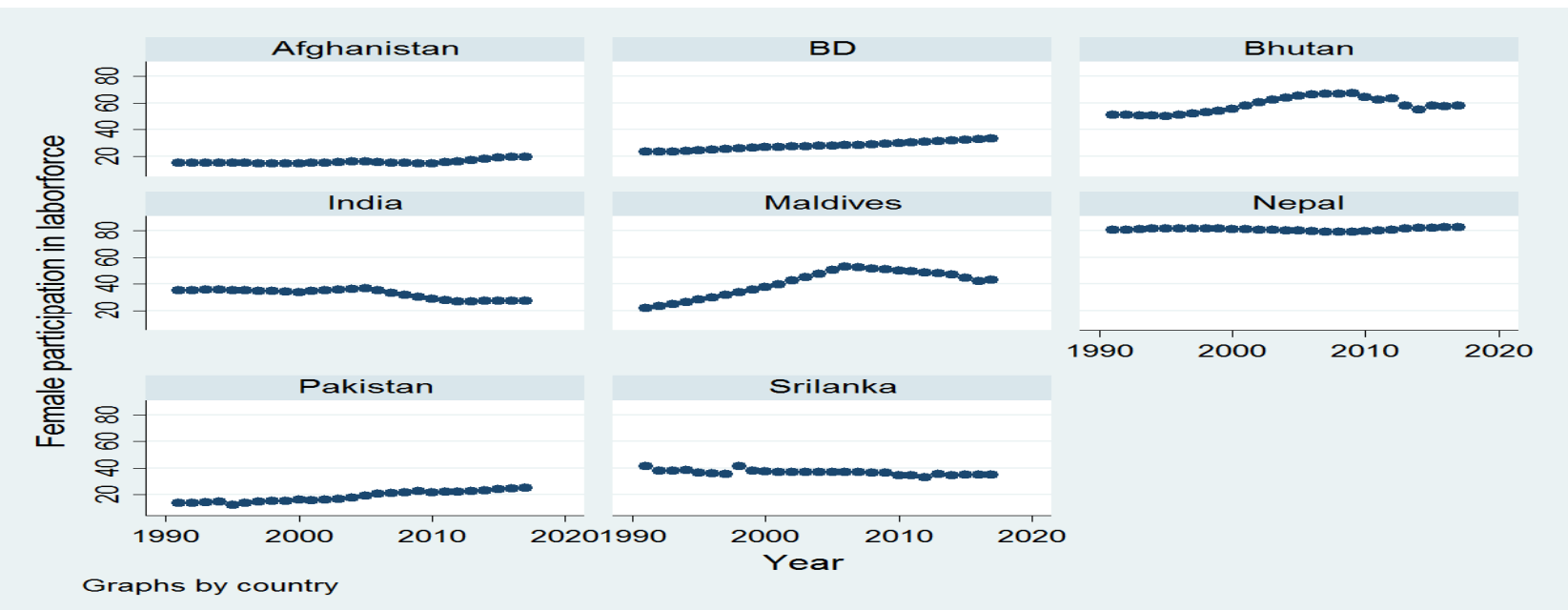

Figure 2. Female labor force participation rate by time for South Asian countries 


\section{Data and Descriptive Evidence}

The data for this paper are drawn from several data sources. First, I use world development indicator (WDI) for most of the cases. My second data sources consist of data on GDP, female literacy rate, and female unemployment rate from specific countries' Government Bureau of Statistics (GBS).The enrolment in education data was collected from UNICEF education database. The population dataset was collected from world population data.

\section{Table 1. Summary Statistics}

\section{Variable}

Time

Trade Openness

Female labor force participation(\%)

Female participation in agri (\%)

Female in industry (\%)

Female in service $(\%)$

Female unemployment (\%)

Male labor force participation(\%)

Male participation in agri (\%)

Male in industry (\%)

Male in service (\%)

Male unemployment $(\%)$

Total unemployment $(\%)$

Population

Women total

Men total

Rural population(\%)

Urban population(\%)

GDP

GDP per capita

Export Good and Service

Export Merchandise

Export Service

Export Food

Import Merchandise

Import Service

Import Good and Service

Import food

Agriculture (\% of GDP)

Women Enrolment in education

$\begin{array}{lllll}\text { Obs } & \text { Mean } & \text { Std. Dev. } & \text { Min } & \text { Max } \\ 216 & 2004 & 7.806974 & 1991 & 2017 \\ 186 & 62.07171 & 37.39863 & 17.17158 & 184.0933 \\ 216 & 38.90346 & 20.774 & 12.50489 & 82.7681 \\ 216 & 62.12731 & 24.72127 & 3.7 & 89.5 \\ 216 & 14.06852 & 9.110236 & 1.5 & 42.9 \\ 216 & 23.80694 & 17.13643 & 6.2 & 76.1 \\ 216 & 6.42037 & 4.912059 & 1 & 23 \\ 216 & 81.54252 & 5.404639 & 67.30968 & 90.78352 \\ 216 & 46.08056 & 15.13954 & 10.6 & 78.8 \\ 216 & 16.85139 & 5.479951 & 4 & 28.6 \\ 216 & 37.06389 & 12.27971 & 17 & 68.3 \\ 216 & 3.703241 & 1.974898 & 0.6 & 10.3 \\ 216 & 4.368981 & 2.606773 & 0.6 & 14.7 \\ 208 & 1.84 \mathrm{E}+08 & 3.60 \mathrm{E}+08 & 227000 & 1.32 \mathrm{E}+09 \\ 208 & 8.89 \mathrm{E}+07 & 1.73 \mathrm{E}+08 & 110968 & 6.38 \mathrm{E}+08 \\ 208 & 9.48 \mathrm{E}+07 & 1.87 \mathrm{E}+08 & 116032 & 6.86 \mathrm{E}+08 \\ 208 & 74.05134 & 7.889866 & 53.46 & 90.82 \\ 208 & 25.94866 & 7.889866 & 9.18 & 46.54 \\ 198 & 1.61 \mathrm{E}+11 & 3.97 \mathrm{E}+11 & 2.35 \mathrm{E}+08 & 2.26 \mathrm{E}+12 \\ 198 & 1354.309 & 1750.474 & 117.4097 & 9875.278 \\ 186 & 3.27 \mathrm{E}+10 & 9.01 \mathrm{E}+10 & 7.43 \mathrm{E}+07 & 4.72 \mathrm{E}+11 \\ 208 & 2.00 \mathrm{E}+10 & 5.57 \mathrm{E}+10 & 5.27 \mathrm{E}+07 & 3.23 \mathrm{E}+11 \\ 176 & 1.06 \mathrm{E}+10 & 3.13 \mathrm{E}+10 & 5.17 \mathrm{E}+07 & 1.62 \mathrm{E}+11 \\ 158 & 25.48985 & 26.07928 & 2.643993 & 98.55777 \\ 208 & 3.02 \mathrm{E}+10 & 8.37 \mathrm{E}+10 & 8.30 \mathrm{E}+07 & 4.90 \mathrm{E}+11 \\ 176 & 7.86 \mathrm{E}+09 & 1.83 \mathrm{E}+10 & 4.21 \mathrm{E}+07 & 9.59 \mathrm{E}+10 \\ 186 & 3.99 \mathrm{E}+10 & 1.06 \mathrm{E}+11 & 1.00 \mathrm{E}+08 & 5.71 \mathrm{E}+11 \\ 157 & 13.97486 & 5.628657 & 2.492372 & 25.59949 \\ 194 & 20.42365 & 10.08022 & 5.738111 & 44.8648 \\ 162 & 9352709 & 1.90 \mathrm{E}+07 & 0 & 7.05 \mathrm{E}+07\end{array}$

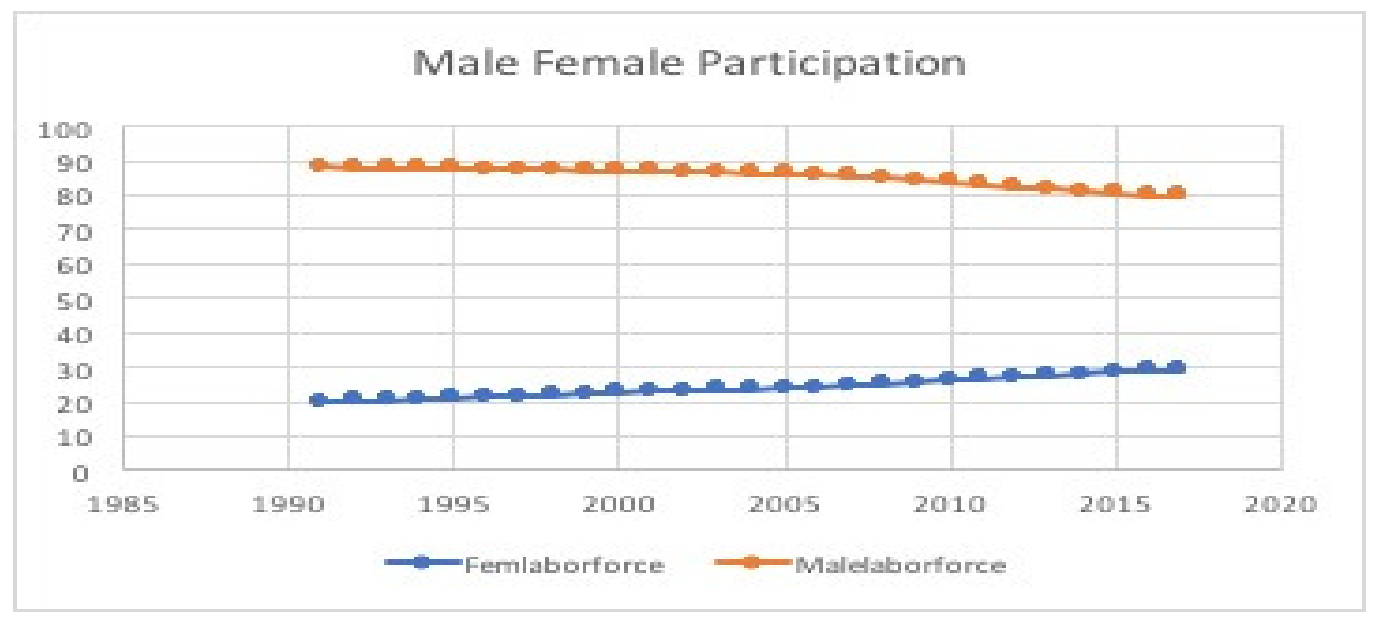

Figure 3. Average male and female labor force participation rate by time for South Asian countries 


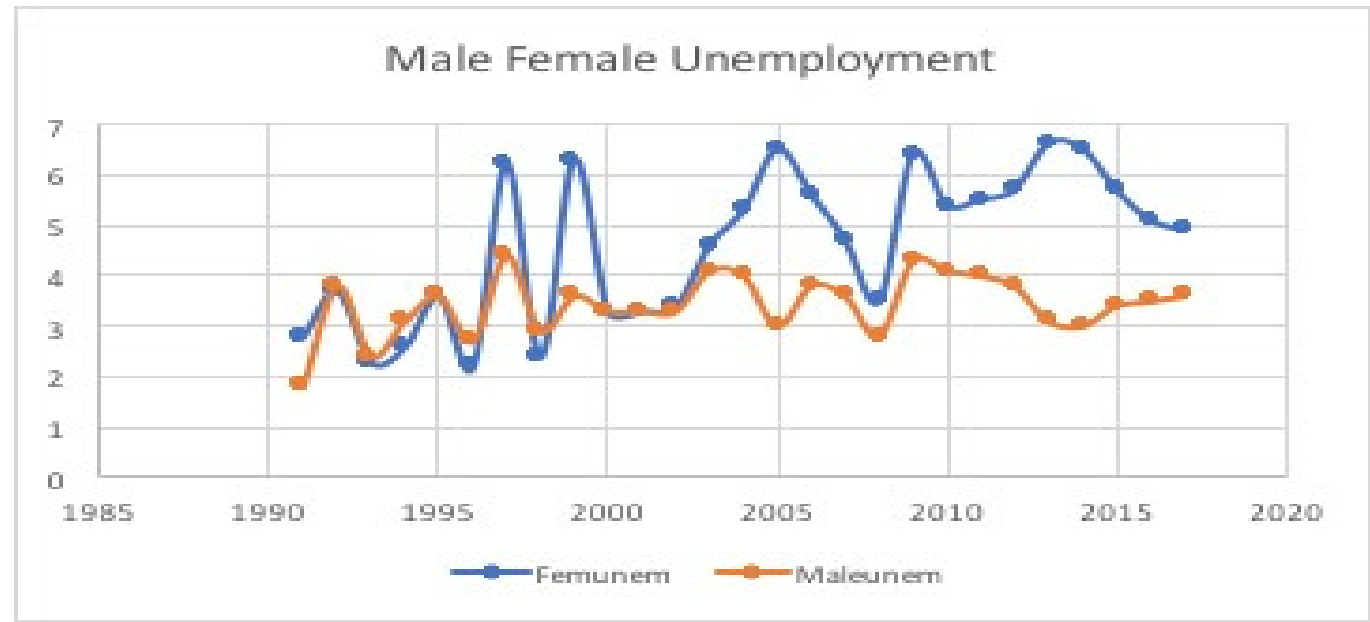

Figure 4. Average male and female unemployment rate by time for South Asian countries

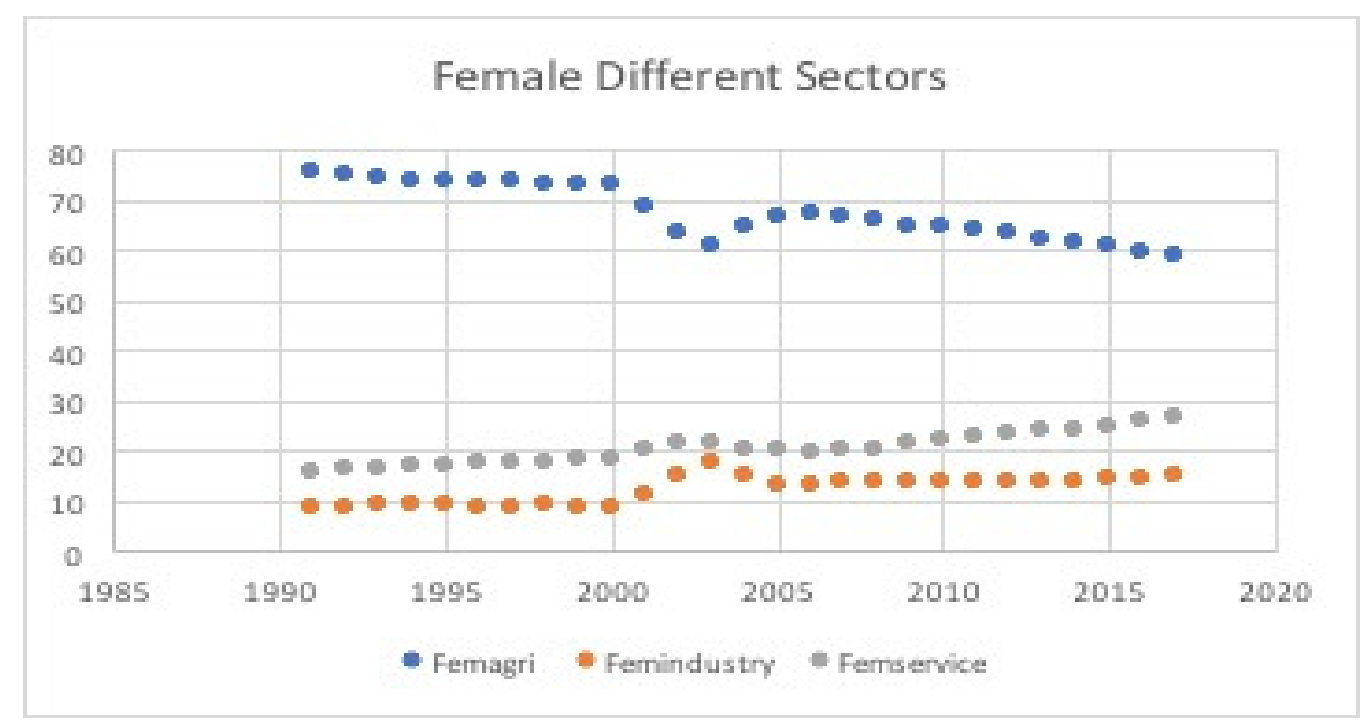

Figure 5: Average female participation rates by time in different sectors in South Asia

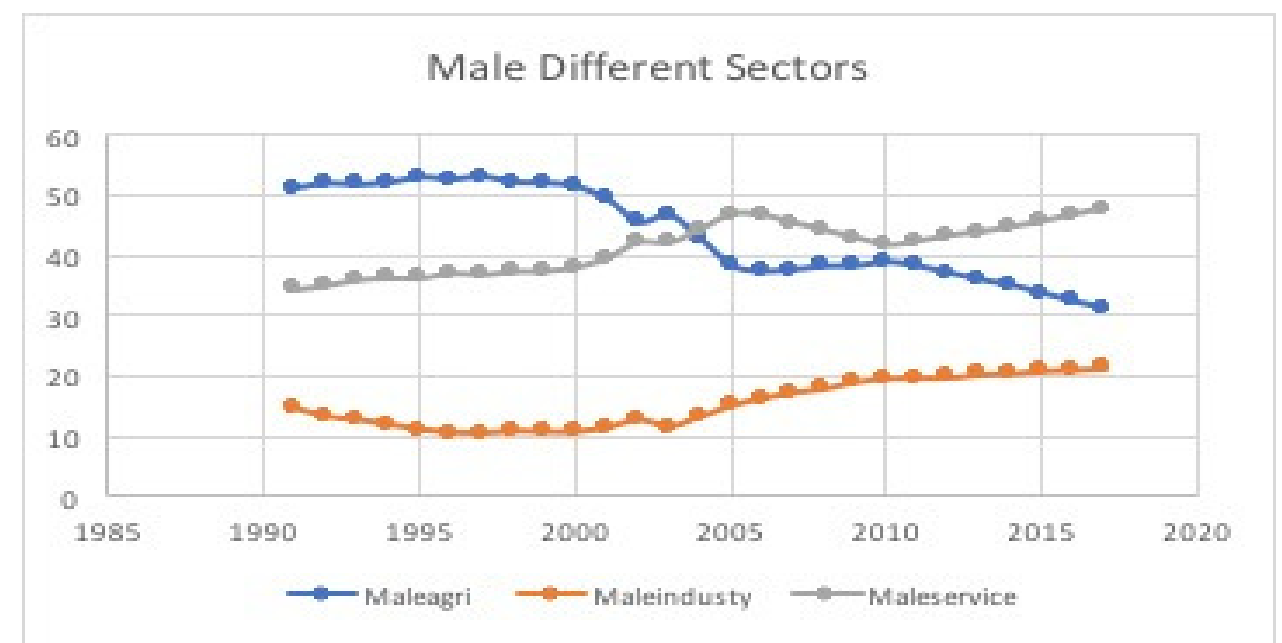

Figure 6. Average male participation rates in different sectors in South Asia

\section{Empirical Framework}

I estimate the reduced-form relationship between trade openness and female participation in labor market using two different data constructs. The first I aggregated all South Asian countries data and constructed a country level panel dataset and estimate the following baseline specification: 
$\mathbf{W P R}_{\mathrm{c}, \mathrm{t}}=\alpha+\beta \mathbf{T} \mathbf{O}_{\mathrm{c}, \mathrm{t}}+\gamma \mathbf{X}_{\mathrm{c}, \mathrm{t}}+\mu_{\mathrm{c}}+\delta_{\mathrm{t}}+\varepsilon_{\mathrm{c}, \mathrm{t}}$

$\mathrm{WPR}_{\mathrm{ct}}$ is the women participation rate in a different year $(\mathrm{t})$ in different countries $\mathrm{c}, \mathrm{TO}_{\mathrm{c}, \mathrm{t}}$ is trade openness measure. $\beta$ here is the parameter estimate of interest. $X_{c, t}$ is other attributes that can affect women labor force participation. To estimate with ambiguity regarding the treatment of the non-tradable sector and to explore the robustness of our results, I will estimate several different versions of equation (1).

TO is here trade openness measure, the trade openness is total export and import percentage of GDP. $\beta$ here is the main parameter of estimate.

The Impact of Trade Openness on Female Labor Market Outcome:

Table 2. Shows the estimation result for equation (1)

Female labor force participation rate-null models

\begin{tabular}{|c|c|c|c|c|c|}
\hline & (1) & (2) & (3) & (4) & $(5)$ \\
\hline Trade Openness & $\begin{array}{l}0.173 * * \\
(2.77)\end{array}$ & $\begin{array}{l}0.146^{* *} \\
(2.73)\end{array}$ & $\begin{array}{l}0.0945^{*} \\
(2.02)\end{array}$ & $\begin{array}{l}0.0685^{*} \\
(1.28)\end{array}$ & $\begin{array}{l}0.0862 \\
(1.50)\end{array}$ \\
\hline GDP per capita & & $\begin{array}{l}0.00108 \\
(-0.95)\end{array}$ & $\begin{array}{l}0.00324 * * \\
(2.89)\end{array}$ & $\begin{array}{l}0.00349 * * \\
(2.80)\end{array}$ & $\begin{array}{l}0.00345 * * \\
(2.76)\end{array}$ \\
\hline Urban population & & & $\begin{array}{l}-1.511 * * * \\
(-7.94)\end{array}$ & $\begin{array}{l}-1.539 * * * \\
(-7.34)\end{array}$ & $\begin{array}{l}-1.504 * * * \\
(-7.03)\end{array}$ \\
\hline Enrolment in education & & & & $\begin{array}{l}-2.86 e-08 \\
(-0.35)\end{array}$ & $\begin{array}{l}-2.59 \mathrm{e}-08 \\
(-0.32)\end{array}$ \\
\hline Male labor force participation rate & & & & & $\begin{array}{l}-0.275 \\
(0.86)\end{array}$ \\
\hline Constant & $\begin{array}{l}33.28 * * * \\
(11.28)\end{array}$ & $\begin{array}{l}32.62 * * * \\
(10.75)\end{array}$ & $\begin{array}{l}69.76^{* * *} \\
(13.01)\end{array}$ & $\begin{array}{l}72.82 * * * \\
(12.41)\end{array}$ & $\begin{array}{l}48.43 \\
(1.67)\end{array}$ \\
\hline $\mathrm{N}$ & 186 & 186 & 186 & 163 & 163 \\
\hline \multicolumn{6}{|c|}{$\begin{array}{l}* \mathrm{p}<0.05, * * \mathrm{p}<0.01, * * * \mathrm{p}<0.001 \\
\text { Table } 2 \text { shows that there is a positive and significant relationship between trade openness and women } \\
\text { participation in the labor force. When we control other variables the magnitude of coefficient decreased but still } \\
\text { significant. } \\
\text { Table 3. Base- log model }\end{array}$} \\
\hline$(1)$ & $(2)$ & (3) & (4) & \multicolumn{2}{|c|}{ (5) } \\
\hline Log Trade Openness & $\begin{array}{l}15.24 * * * \\
(4.84)\end{array}$ & $\begin{array}{l}7.951 * * \\
(2.84)\end{array}$ & $\begin{array}{l}9.609^{*} \\
(2.42)\end{array}$ & \multicolumn{2}{|c|}{$\begin{array}{l}8.956^{*} \\
(2.24)\end{array}$} \\
\hline Log GDP per capita & $\begin{array}{l}5.333 * * \\
(-2.78)\end{array}$ & $\begin{array}{l}5.217^{*} \\
(2.56)\end{array}$ & $\begin{array}{l}6.519 * * \\
(2.76)\end{array}$ & \multicolumn{2}{|c|}{$\begin{array}{l}7.378 * * \\
(3.01)\end{array}$} \\
\hline Log Urban population & & \multirow[t]{2}{*}{$\begin{array}{l}-39.55^{* * *} \\
(-8.59)\end{array}$} & $\begin{array}{l}-42.42 * * * \\
(-7.93)\end{array}$ & \multicolumn{2}{|c|}{$\begin{array}{l}-40.48^{* * * *} \\
(-7.29)\end{array}$} \\
\hline $\begin{array}{l}\text { Log Enrolment in } \\
\text { education }\end{array}$ & & & $\begin{array}{l}1.080 \\
(1.25)\end{array}$ & \multicolumn{2}{|c|}{0.420} \\
\hline $\begin{array}{l}\text { Male labor force } \\
\text { participation rate }\end{array}$ & & & & \multicolumn{2}{|c|}{0.531} \\
\hline \multirow[t]{2}{*}{ Constant } & $\begin{array}{l}15.27 \\
(1.23)\end{array}$ & $\begin{array}{l}100.9 * * * \\
(6.97)\end{array}$ & $\begin{array}{l}80.76^{* *} \\
(3.04)\end{array}$ & \multicolumn{2}{|c|}{$\begin{array}{l}37.03 \\
(0.85)\end{array}$} \\
\hline & 186 & 186 & 163 & & \\
\hline
\end{tabular}

$\mathrm{t}$ statistics in parentheses

$* \mathrm{p}<0.05, * * \mathrm{p}<0.01, * * * \mathrm{p}<0.001$

Table 3 shows that there is a positive and significant relationship between log of trade openness and women participation in the labor force. Also, log of GDP per capita has positive impact on labor force participation rate. 
Table 4. Log-log model

Log of Female labor force participation rate

\begin{tabular}{llllll}
\hline & $(1)$ & $(2)$ & $(3)$ & $(4)$ & $(5)$ \\
\hline Log Trade Openness & $0.392 * * *$ & $0.329 * * *$ & $0.139 *$ & 0.154 & 0.153 \\
& $(4.32)$ & $(4.15)$ & $(2.01)$ & $(1.91)$ & $(1.82)$ \\
Log GDP per capita & & -0.0435 & $0.231 * * *$ & $0.234 * * *$ & $0.233^{* * *}$ \\
& & $(-0.90)$ & $(4.58)$ & $(4.31)$ & $(3.88)$ \\
Log Enrolment in & & $-1.030^{* * *}$ & $-1.075^{* * *}$ & $-1.075^{* * *}$ \\
education & & & & $(-8.65)$ & $(-8.62)$ \\
Log Urban population & & $(-9.01)$ & $3.03 \mathrm{e}-09$ & $3.02 \mathrm{e}-09$ \\
& & & $(1.55)$ & $(1.53)$ \\
Male labor force & & & & -0.000334 \\
participation rate & & & & $(-0.04)$ \\
& & & & $4.825 * * *$ & $4.862 * * *$ \\
Constant & $2.401 * * *$ & $2.542 * * *$ & $4.772 * * *$ & $(12.11)$ & $(4.49)$ \\
\hline $\mathrm{N}$ & $(8.87)$ & $(8.13)$ & $(13.27)$ & 163 & 163 \\
\hline
\end{tabular}

$t$ statistics in parentheses

$* p<0.05, * * p<0.01, * * * p<0.001$

Table 4 shows the log-log model. The coefficient of log-log model displays the elasticity of our women participation and trade openness. In other explanations, the coefficient is here shows the percentage change of women participation rate for a percent change in trade openness. In our model 1 , if trade openness goes up by $1 \%$, women participation rate goes up by $.39 \%$.

Table 5. Log-Log model

Log of Female labor force participation rate

\begin{tabular}{lllll}
\hline & $(1)$ & $(2)$ & $(3)$ & $(4)$ \\
\hline $\log$ (Trade Openness) & $10.64 * * *$ & $8.98^{* *}$ & $7.951 * *$ & $6.716^{*}$ \\
& $(3.90)$ & $(3.52)$ & $(2.84)$ & $(2.05)$ \\
Log (Enrolment in education) & & & -8.59 & -7.94 \\
& & & $(0.25)$ & $1.96 \mathrm{e}-08$
\end{tabular}

Log (Trade Openness*

GDP per capita)

Log (Trade Openness*

Enrolment)

\section{$2.492 *$}

\begin{tabular}{lllll} 
Constant & -1.997 & $27.14^{* * *}$ & $100.9^{* * *}$ & $\begin{array}{l}106.7^{* * *} \\
(6.58)\end{array}$ \\
\hline $\mathrm{N}$ & $(-0.18)$ & $(4.25)$ & $(6.97)$ & 186 \\
\hline
\end{tabular}

t statistics in parentheses

$* p<0.05, * * p<0.01, * * * p<0.001$

Table 5 shows interaction terms' coefficients. The joint effect of log of trade openness and GDP per capita is positive and significant. On the other hand, the joint effect of log of trade openness and enrolment is negative and insignificant.

\section{Effect of Trade Openness on women participation rate in different sectors:}

$\mathbf{W P R}_{\mathrm{j}, \mathrm{c}, \mathrm{t}}=\alpha+\beta \mathrm{TO}_{\mathrm{j}, \mathrm{c}, \mathrm{t}}+\gamma \mathbf{X}_{\mathrm{j}, \mathrm{c}, \mathrm{t}}+\mu_{\mathrm{c}}+\pi_{\mathrm{j}}+\delta_{\mathrm{t}}+\varepsilon_{\mathrm{c}, \mathrm{t}} \ldots \ldots \ldots \ldots \ldots \ldots \ldots$ (2)

I included three sectors in the equation (2). To find out how much effect of trade openness on the women participation in agriculture, industry, and service sectors I applied equation (2). 
Table 6. Women participation rate in agriculture

Log of female labor force participation rate in agriculture sector

\begin{tabular}{|c|c|c|c|c|c|}
\hline & (1) & $(2)$ & (3) & (4) & (5) \\
\hline Log (Trade Openness) & $\begin{array}{l}.731 * * * \\
(-9.90)\end{array}$ & $\begin{array}{l}-0.344 * * * \\
(-5.07)\end{array}$ & $\begin{array}{l}-0.327 * * * \\
(-4.59)\end{array}$ & $\begin{array}{l}-0.328 * * * \\
(-4.08)\end{array}$ & $\begin{array}{l}-0.242 * * * \\
(-5.73)\end{array}$ \\
\hline Log (GDP per capita) & & $\begin{array}{l}-0.449 * * * \\
(-10.89)\end{array}$ & $\begin{array}{l}-0.473 * * * \\
(-9.14)\end{array}$ & $\begin{array}{l}-0.484 * * * \\
(-8.93)\end{array}$ & $\begin{array}{l}-0.608 * * * \\
(-11.01)\end{array}$ \\
\hline Log(Urban population) & & & $\begin{array}{l}0.0904 \\
(0.77)\end{array}$ & $\begin{array}{l}0.0887 \\
(0.72)\end{array}$ & $\begin{array}{l}0.0642 \\
(0.56)\end{array}$ \\
\hline Log (Enrolment) & & & & $\begin{array}{l}-1.38 \mathrm{e}-10 \\
(-0.07)\end{array}$ & $\begin{array}{l}-8.50 \mathrm{e}-10 \\
(-0.47)\end{array}$ \\
\hline $\begin{array}{l}\text { Male labor force } \\
\text { Participation }\end{array}$ & & & & & $\begin{array}{l}-0.0433 * * * \\
(-5.30)\end{array}$ \\
\hline Constant & $\begin{array}{l}6.928 * * * \\
(23.38)\end{array}$ & $\begin{array}{l}8.383 * * * \\
(31.38)\end{array}$ & $\begin{array}{l}8.188 * * * \\
(22.21)\end{array}$ & $\begin{array}{l}8.283 * * * \\
(20.86)\end{array}$ & $\begin{array}{l}13.18 * * * \\
(13.25)\end{array}$ \\
\hline $\mathrm{N}$ & 558 & 558 & 558 & 489 & 489 \\
\hline
\end{tabular}

$\mathrm{t}$ statistics in parentheses

$* \mathrm{p}<0.05, * * \mathrm{p}<0.01, * * * \mathrm{p}<0.001$

Table 7. Women participation rate in industry

Log of female labor force participation rate in industrial sector

\begin{tabular}{llllll}
\hline & $(1)$ & $(2)$ & $(3)$ & $(4)$ & $(5)$ \\
\hline Log (Trade Openness) & $0.177^{*}$ & $0.108^{*}$ & $-0.209^{*}$ & -0.146 & -0.204 \\
& $(2.12)$ & $(-2.52)$ & $(-2.41)$ & $(-1.45)$ & $(-1.97)$ \\
Log (GDP per capita) & & & & & \\
& & $0.446^{* * *}$ & $0.448^{* * *}$ & $0.450^{* * *}$ & $0.388^{* * *}$ \\
& $(8.91)$ & $(7.12)$ & $(6.65)$ & $(5.24)$ \\
Log (Urban population) & & & & -0.107 \\
& & -0.00784 & -0.0942 & $(-0.69)$ \\
Log (Enrolment) & & $(-0.05)$ & $(-0.61)$ & $4.92 \mathrm{e}-09 *$ \\
& & & & $(2.03)$ \\
Male labor force & & & & $(2.16)$ & $-0.0218^{*}$ \\
Constant & & & & $(-2.00)$ \\
& & & & & $2.724 *$ \\
$\mathrm{~N}$ & $1.713^{* * *}$ & 0.267 & 0.284 & 0.251 & $(2.04)$ \\
\hline
\end{tabular}

$t$ statistics in parentheses

$* p<0.05, * * p<0.01, * * * p<0.001$ 
Table 8. Women participation rate in service sector

Log of female labor force participation rate in service sector

\begin{tabular}{|c|c|c|c|c|c|}
\hline & (1) & $(2)$ & (3) & (4) & $(5)$ \\
\hline Log (Trade Openness) & $\begin{array}{l}0.488 * * * \\
(7.73)\end{array}$ & $\begin{array}{l}0.0822^{*} \\
(1.73)\end{array}$ & $\begin{array}{l}0.0688 \\
(1.38)\end{array}$ & $\begin{array}{l}0.0565 \\
(1.00)\end{array}$ & $\begin{array}{l}0.000837 \\
(-0.01)\end{array}$ \\
\hline Log (GDP per capita) & & $\begin{array}{l}0.470 * * * \\
(16.25)\end{array}$ & $\begin{array}{l}0.490^{* * *} * \\
(13.48)\end{array}$ & $\begin{array}{l}0.497 * * * \\
(13.02)\end{array}$ & $\begin{array}{l}0.435^{* * *} \\
(10.71)\end{array}$ \\
\hline Log (Urban population) & & & $\begin{array}{l}-0.0728 \\
(-0.89)\end{array}$ & $\begin{array}{l}-0.0363 \\
(-0.42)\end{array}$ & $\begin{array}{l}-0.0485 \\
(-0.57)\end{array}$ \\
\hline Enrolment & & & & $\begin{array}{l}-2.80 \mathrm{e}-09^{*} \\
(-2.04)\end{array}$ & $\begin{array}{l}-3.16 \mathrm{e}-09 * \\
(-2.37)\end{array}$ \\
\hline Male labor force & & & & & $\begin{array}{l}-0.0216^{* * *} \\
(-3.60)\end{array}$ \\
\hline Constant & $\begin{array}{l}1.011^{* * *} \\
(4.00)\end{array}$ & $\begin{array}{l}-0.511 * * \\
(-2.73)\end{array}$ & $\begin{array}{l}-0.353 \\
(-1.37) \\
\end{array}$ & $\begin{array}{l}-0.458 \\
(-1.64) \\
\end{array}$ & $\begin{array}{l}1.989 * * \\
(2.72)\end{array}$ \\
\hline $\mathrm{N}$ & 186 & 186 & 186 & 163 & 163 \\
\hline
\end{tabular}

\section{Conclusion}

While there is a vast amount of literature analyzing the impacts of trade reform and trade openness on GDP, growth, development, other macroeconomic variables, very little is known about the women participation rate effects of trade openness. The main purpose of this paper is to fill this gap by analyzing the trade openness in South Asian countries on female labor force participation rate. Once South Asian region was one of the most heavily protected economics in the world until the first 1990s. Female labor force participation in South Asian region increased from 34 to 43 percent, also I showed that trade openness made faster increase in female labor force participation and employment.

This paper contributes in several ways to the academic literature, economists, and policy debate on the distributional, women empowerment, and gender effects of trade openness. Women participation in economic activities with trade openness unanimously as an indicator of progress. Also, a declining gender gap in the job market is arguably an important step towards equality between male and female in the job sectors. The paper's empirical outcomes suggest that trade openness created new horizon for women.

Also, estimation shows that trade openness decreases female labor from agriculture sector and creates positive relationship with women participation in service and industry. It is established that, service and manufacturing sectors directly related with export. In the South Asian countries percentage of agriculture in GDP has been decreasing and percentage of service and manufacturing in GDP has been increasing.

\section{References}

Asma Hyder, and Jere R. Behrman. 2012, International trade openness and gender gaps in Pakistani labor force participation rates over 57 years. National University of Science and technology. Islamabad. PSC working paper series.

https://repository.upenn.edu/cgi/viewcontent.cgi?referer=https:/www.google.com/\&httpsredir=1\&article=1024 \&context=psc_work_papers

Bussmann, Margit. 2009. The Effect of Trade Openness on Women 's Welfare and Work Life, World Development, Vol. 37(6), 1027-1038. https://ideas.repec.org/a/eee/wdevel/v37y2009i6p1027-1038.html

Cem Baslevent, and Ozlem Onaran. 2004. The Effect of Export-Oriented Growth on Female Labor Market Outcomes in Turkey. World Development, Elsevier. Vol 32(8).

Janna Besamusca, Kea Tijdens, Steinmetz S., and Maarten Keune. 2015. Working Women Worldwide. Age Effects in Female Labor Force Participation in 117 Countries. Elsevier, vol. 74, C, pages 123-141

Ramessur, Taruna S.Sobhee, and Sanjeev K. 2009. Impact of trade liberalization on labor conditions on the textile sector of Mauritius: the fate of female workers Vol. 9-2. Regional and Sectoral Economic Studies. (2009) https://ideas.repec.org/a/eaa/eerese/v9y2009i9_11.html

Isis Gaddis and Janneke Pieters. 2012, Trade Liberalization and Female Labor Force Participation: Evidence from Brazil. Institute for the study of labor. DP No. 6809. August 2012. http://repec.iza.org/dp6809.pdf

Edward E. Leamer. 1995. The Heckscher-Ohlin Model in theory and practice. No. 77, February 1995, International Finance Section.

Princeton University, NJ. https://www.princeton.edu/ ies/IES_Studies/S77.pdf

Engelhardt, Henriette, \& Prskawetz, Alexia (2004). On the changing correlation between fertility and female employment over space and time. European Journal of Population, printed in Netherlands. 20(1), 35-62. 
Mohammad Monjurul Hoque, Zulkornain Yusop, 2012. Impacts of Trade Liberalization on Export Performance in Bangladesh: An Empirical Investigation. South Asian Economic Journal. http://journals.sagepub.com/doi/abs/10.1177/1391561412457235

Rejaul Karim Byron and Md Fazlur Rahman. Women working grow fast, 2018. http://www.thedailystar.net/frontpage/women-workforce-growing-fast-15514913.

Rees, Ray and Apps, Patricia (2001). Fertility, female labor supply and public policy. Institute for the Study of Labor (IZA) Discussion Papers, 409.

Revenga, Ana (1997). Employment and Wage Effects of Trade Liberalization: The Case of Mexican Manufacturing, Journal of Labor Economics, 15 (3), 520-543

Rahman, Mohammad Mafizur (2011) Trade liberalization and gender gap: Bangladesh experience. In: ETSG 2011: 13th Annual

Conference of the European Trade Study Group, Copenhagen, Denmark. Journal of Asian development study. https://eprints.usq.edu.au/20801/

Appendix 1. List of countries
\begin{tabular}{|l|l|}
\hline Countries & Income level \\
\hline Afghanistan & Low-Income Country \\
\hline Bangladesh & Lower Middle-Income Country \\
\hline Bhutan & Lower Middle-Income Country \\
\hline India & Lower Middle-Income Country \\
\hline Maldives & Low-Income Country \\
\hline Nepal & Low-Income Country \\
\hline Pakistan & Lower Middle-Income Country \\
\hline Sri Lanka & Lower Middle-Income Country \\
\hline
\end{tabular}

